\title{
Intestinal digestibility of enriched-protein fodders measured by mobile bag incubated with or without pepsin-HCl and three-step techniques
}

\author{
P. Paengkoum ${ }^{1 \#}$, S. Traiyakun ${ }^{1} \&$ S. Paengkoum ${ }^{2}$ \\ ${ }^{1}$ School of Animal Production Technology, Institute of Agricultural Technology, Suranaree University of Technology, \\ Muang, Nakhon Ratchasima, 30000, Thailand \\ ${ }^{2}$ Faculty of Science and Technology, Nakhon Ratchasima Rajabhat University, Nakhon Ratchasima 30000, Thailand
}

(Received 24 August 2012; Accepted 29 August 2013; First published online 30 December 2013)

Copyright resides with the authors in terms of the Creative Commons Attribution 2.5 South African Licence.

See: http://creativecommons.org/licenses/by/2.5/za

Condition of use: The user may copy, distribute, transmit and adapt the work, but must recognise the authors and the South African Journal of Animal Science.

\begin{abstract}
Ruminal, intestinal and total tract digestibility of dry matter (DM) and crude protein (CP) of leucaena (Leucaena leucocephala), Madras thorn (Pithecellobium dulce) and moringa (Moringa oleifera) fodders were measured in this study, using nylon bag and mobile bag techniques. Three cattle were fitted with permanent rumen and duodenal cannulae. Intestinal digestibility was measured using the mobile nylon bag (MNB) technique with or without incubation in a pepsin- $\mathrm{HCl}$ solution, and a three-step in vitro technique. The rate of ruminal disappearances of DM and CP, and the potential degradation of CP from nylon bags of both Madras thorn and moringa fodders were significantly higher than that for leucaena fodder. Potential degradation (A+B) values of CP were $45.6 \%, 54.2 \%$ and $52.8 \%$ for leucaena, Madras thorn and moringa fodders, respectively. Average DM and CP digestibility in the intestine and total tract for both Madras thorn and moringa fodders were significantly higher than for leucaena fodder. Average digestibility of DM and CP in the intestine and total tract measured using MNB without pepsin- $\mathrm{HCl}$ solution was significantly lower than with pepsin- $\mathrm{HCl}$ and with the three-step methods. These data suggest that the results of in vivo and in vitro methods for estimating intestinal digestibility are similar, though in all methods the incubation in a pepsin- $\mathrm{HCl}$ solution is necessary.
\end{abstract}

Keywords: Intestinal digestibility, protein fodder, mobile nylon bag, a three-step technique

${ }^{\#}$ Corresponding author: pramote@sut.ac.th

\section{Introduction}

Recently developed protein evaluation systems for ruminants require data on the degradability of feed protein in the rumen and intestine, which can be estimated by in vivo and in vitro methods. The in vivo measurement of nutrient digestion in the rumen and intestine requires that the animal be surgically prepared with cannulae in both the rumen and duodenum. With these methods, the crude protein (CP) disappearance of a large number of feedstuffs can be measured in the rumen (Ørskov \& McDonald, 1979) and intestine, using the mobile nylon bag (MNB) techinque (De Boer et al., 1987). In the development of the MNB technique in ruminants some problems have been encountered such as length of incubation in the rumen, site of bag recovery and the necessity or not of subjecting a feed to acid digestion in the abomasum before determining intestinal digestibility (Becker et al., 1996). Variations in in vivo intestinal digestion among protein supplements have been reported (Waltz et al., 1989; Stern et al., 1997). Obtaining estimates of protein digestion in the small intestine are expensive and labour intensive, and require the use of intestinally surgically prepared animals. Various in vitro laboratory techniques have been used to predict intestinal digestion of proteins in ruminant feed ingredients, including pepsin- $\mathrm{HCl}$ with the $\mathrm{MNB}$ method (Antoniewicz et al., 1992; Van Straalen et al., 1993) and the three-step technique (Calsamiglia \& Stern, 1995). 
A potential strategy for increasing the quality and availability of feed for small ruminants in the dry season may be through the use of fodder from trees and shrubs (Preston \& Leng 1987; Sanchez et al., 2006), because supplementation with high protein and energy concentrates involves extra costs. Fodder from locally grown shrubs and trees such as moringa (Moringa oleifera), neem (Azadirachta indica) and leucaena (Leucaena leucocephala) has been tested as sources of protein supplements for ruminants (Aranachal et al., 2002; Sanchez et al., 2006; Kahindi et al., 2007; Paengkoum \& Paengkoum, 2010; Paengkoum, 2010). These fodders have proven to be effective as protein sources, with significant increases in productivity and performance of ruminants (Kahindi et al., 2007; Saha et al., 2008; Paengkoum \& Paengkoum, 2010).

The objectives of the present study were to evaluate ruminal and intestinal degradation of protein in tropical fodders; and to compare results between intestinal digestion based on the MNB technique with and without pepsin- $\mathrm{HCl}$, and the three-step in vitro techniques.

\section{Materials and Methods}

Fodder from three fodder trees/shrubs, leucaena (L. leucocephala), Madras thorn (Pithecellobium dulce) and moringa (M. oleifera), were harvested: About $10-30 \mathrm{~cm}$ of the growing points of the plants (about six weeks of growth) were cut and oven-dried at $60{ }^{\circ} \mathrm{C}$ for $48 \mathrm{~h}$, ground through a 2-mm screen sieve and stored pending chemical analyses, nylon bag and mobile bag studies.

Ruminal dry matter (DM) and CP digestibility of the fodder were measured using three steers (330 \pm $16 \mathrm{~kg}$; and 4 - 5 years old), each fitted with a permanent rumen and duodenal cannulae, and kept in individual pens ( $3 \times 5 \mathrm{~m}$ ). The ethical treatment of the animals was approved by the Suranaree University of Technology Committee. The cattle were fed a maintenance diet (1.5\% body weight) of $70 \%$ roughage and $30 \%$ supplements, the latter consisting of equal portions of leucaena, Madras thorn and moringa fodders. The daily feed was offered in two equal portions, at 08:30 and at 16:30. Drinking water was available at all times. A preliminary period lasting 14 days was followed by a seven-day experimental period.

Dry matter and CP disappearance in the rumen were determined in the cattle. Bags $(6 \mathrm{x} 12 \mathrm{~cm})$ made from polyester cloth with a pore size of $45 \mu \mathrm{m}$ (Ørskov \& McDonald, 1979) were each filled with approximately $5 \mathrm{~g}$ of the test material. All samples were prepared in duplicates and incubated in the rumen of each animal for 2, 4, 8, 16, 24, 48 and $72 \mathrm{~h}$. After the specified incubation periods, the bags were removed from the rumen, washed immediately in a washing machine for $10 \mathrm{~min}$, and dried in an oven at $60{ }^{\circ} \mathrm{C}$ for $48 \mathrm{~h}$. Control bags without incubation $(0 \mathrm{~h})$ were washed and dried, following the same procedure as the incubated bags. The bags were weighed and tested according to the procedure described by Ørskov \& McDonald (1979).

Another set of samples (in duplicates) of the test fodders was prepared, incubated for $16 \mathrm{~h}$ in the rumen of the steers, and washed and dried as described above. Dried ruminal residue from the bags was used to measure intestinal disappearance of DM and CP using the mobile bag method described by De Boer et al. (1986). About $0.5 \mathrm{~g}$ of the ruminal residues from each of the three protein samples was placed in mobile bags $(3.5 \times 5 \mathrm{~cm})$ in duplicates and sealed with a heat-sealing machine. The bags were then inserted through the duodenal cannulae into the duodenums of the animals at intervals of three hours. Twelve bags were inserted in each steer per day. The mobile bags recovered from the faeces were washed and dried to estimate intestinal DM and CP disappearance.

Dried residue in the bags recovered from the rumen was used to measure intestinal disappearance, using the MNB with the pepsin-HCl method, described by Van Vuuren et al. (1989) and Van Straalen et al. (1993). About $0.5 \mathrm{~g}$ of the ruminal residues from each of the protein fodders was placed in a mobile bag (in duplicate) and sealed with a heat-sealing machine. Eighteen bags per sample and per animal were incubated in pepsin- $\mathrm{HCl}$ to simulate the digestion in the abomasum. Prior to intestinal incubation, the bags were incubated in pepsin- $\mathrm{HCl}$ solution (0.1 M with pepsin $1 \mathrm{~g} / \mathrm{L}$ (Sigma P-7012, Sigma) for 1,2 or $3 \mathrm{~h}$ at $37^{\circ} \mathrm{C}$. The bags were then inserted into the duodenal cannulae of the same animals at intervals of three hours. A total of 18 bags were inserted in each animal. The mobile bags recovered from the faeces were washed and dried to estimate intestinal DM and CP disappearance.

The dried ruminal residue from the bags was used to measure intestinal disappearance, using a threestep technique described by Calsamiglia \& Stern (1995). The samples were weighed, each containing $15 \mathrm{mg}$ of residual $\mathrm{N}$, into a $50 \mathrm{~mL}$ centrifugation tube. Ten $\mathrm{mL}$ of a $\mathrm{pH} 1.9,0.1 \mathrm{~N} \mathrm{HCl}$ solution containing $1 \mathrm{~g} / \mathrm{L}$ of pepsin (Sigma P-7012, Sigma) was added, vortexed, and incubated for $1 \mathrm{~h}$ in a $30{ }^{\circ} \mathrm{C}$ shaker water bath. 
After incubation, $0.5 \mathrm{~mL}$ of a $1 \mathrm{~N} \mathrm{NaOH}$ solution and $13.5 \mathrm{~mL}$ of a pancreatin solution $\left(0.5 \mathrm{M} \mathrm{KH}_{2} \mathrm{PO}_{4}\right)$ buffer standardized at $\mathrm{pH} 7.8$ containing $50 \mathrm{mg}$ thymol/kg and $3 \mathrm{~g} / \mathrm{L}$ of pancreatin (Sigma P-7545, Sigma) were added, then vortexed and incubated at $38{ }^{\circ} \mathrm{C}$ for $24 \mathrm{hr}$ in a shaker water bath. Samples were vortexed approximately every $8 \mathrm{~h}$. Immediately after incubation, $3 \mathrm{~mL}$ of a $100 \%$ (wt/vol) solution of trichloroacetic acid (TCA) was added to each tube to stop enzymatic action and precipitate undigested proteins. All tubes were vortexed and allow to stand for $15 \mathrm{~min}$. Samples were centrifuged at $10000 \mathrm{x} g$ for 15 min and the supernatant analysed for soluble $\mathrm{N}$ by the Kjeldahl method (AOAC, 1980). Pepsin-pancreatin digestion of protein was calculated as TCA-soluble $\mathrm{N}$ divided by quantity of sample $\mathrm{N}$ (bag residue) used in the assay.

The fodder samples were analysed for DM, ash and Kjeldahl-N according to AOAC (1985). Neutral detergent fibre (NDF) and acid detergent fibre (ADF) were determined by using the method of Goering \& Van Soest (1970).

Data for ruminal and intestinal degradation of DM and CP were fitted to the exponential equation following procedure described by Ørskov \& McDonald (1979):

$$
\mathrm{P}=\mathrm{A}+\mathrm{B}\left(1-\mathrm{e}^{-\mathrm{ct}}\right)
$$

where $\mathrm{P}$ is degradation at time $\mathrm{t}(\%)$ of incubation (h); A is the intercept of the degradation curve at time zero (\%); B is the fraction of DM and CP that will be degraded when given sufficient time for digestion in the rumen (\%); and c is a rate constant of disappearance of fraction B (/h). The effective degradability (ED) of DM and CP were, therefore, calculated using the following equation (Ørskov \& McDonald, 1979);

$$
\mathrm{ED}=\mathrm{A}+(\mathrm{B})(\mathrm{c}) /(\mathrm{c}+\mathrm{k})
$$

where $\mathrm{k}$ is the solid outflow rate from the rumen $(0.05 / \mathrm{h})$. Calculation were done in this study using the NEWAY programme (Chen, 1996) and data were subjected to analysis of variance using SAS software (SAS, 1998). The difference between treatment means was statistically compared using Duncan's New Multiple Range Test (Steel \&Torries, 1980).

\section{Results}

The chemical compositions of the Madras thorn fodder, leucaena fodder and moringa fodder are shown in Table 1. All three protein fodders had similar concentrations of DM, organic matter (OM) and ADF but Madras thorn fodder contained more CP than leucaena and moringa fodder.

Table 1 Chemical composition of tree fodder from Madras thorn, leucaena and moringa ( $\mathrm{g} / \mathrm{kg}$ dry matter)

\begin{tabular}{lccc}
\hline Items & Leucaena & Madras thorn & Moringa \\
\hline Dry matter & 951 & 923 & 935 \\
Organic matter & 879 & 882 & 897 \\
Crude protein & 191 & 237 & 184 \\
Neutral detergent fibre & 486 & 413 & 326 \\
Acid detergent fibre & 201 & 204 & 192 \\
\hline
\end{tabular}

Ruminal DM and CP disappearance rates of protein fodders are shown in Figure 1. Ruminal DM and $\mathrm{CP}$ disappearance rates increased with rumen incubation times, and were most rapid for all fodders at $2 \mathrm{~h}$ to $16 \mathrm{~h}$ of the incubation. The DM and CP disappearance rates of both Madras thorn and moringa fodders were higher $(P<0.05)$ than that of leucaena fodder. The loss of DM by washing $(\mathrm{A})$ of both Madras thorn and moringa fodders was higher $(P<0.05)$ than for leucaena fodder. The DM degradability of insoluble but degradable fraction $\mathrm{B}, \mathrm{DM}$ potential degradation $(\mathrm{A}+\mathrm{B})$ and $\mathrm{DM}$ effective degradability $(\mathrm{E})$ of Madras thorn and moringa fodders were significantly higher $(P<0.05)$ than for leucaena fodder. Similar to the $\mathrm{CP}$ 
degradability of insoluble degradable fraction $\mathrm{B}$, the $\mathrm{CP}$ potential degradation $(\mathrm{A}+\mathrm{B})$ and $\mathrm{CP}$ effective degradability $(\mathrm{E})$ of Madras thorn and moringa fodders were significantly higher $(P<0.05)$ than for leucaena fodder. However, DM and CP degradation rate constants $(c)$ were not significantly $(P<0.05)$ different between the protein fodders.

a) DM

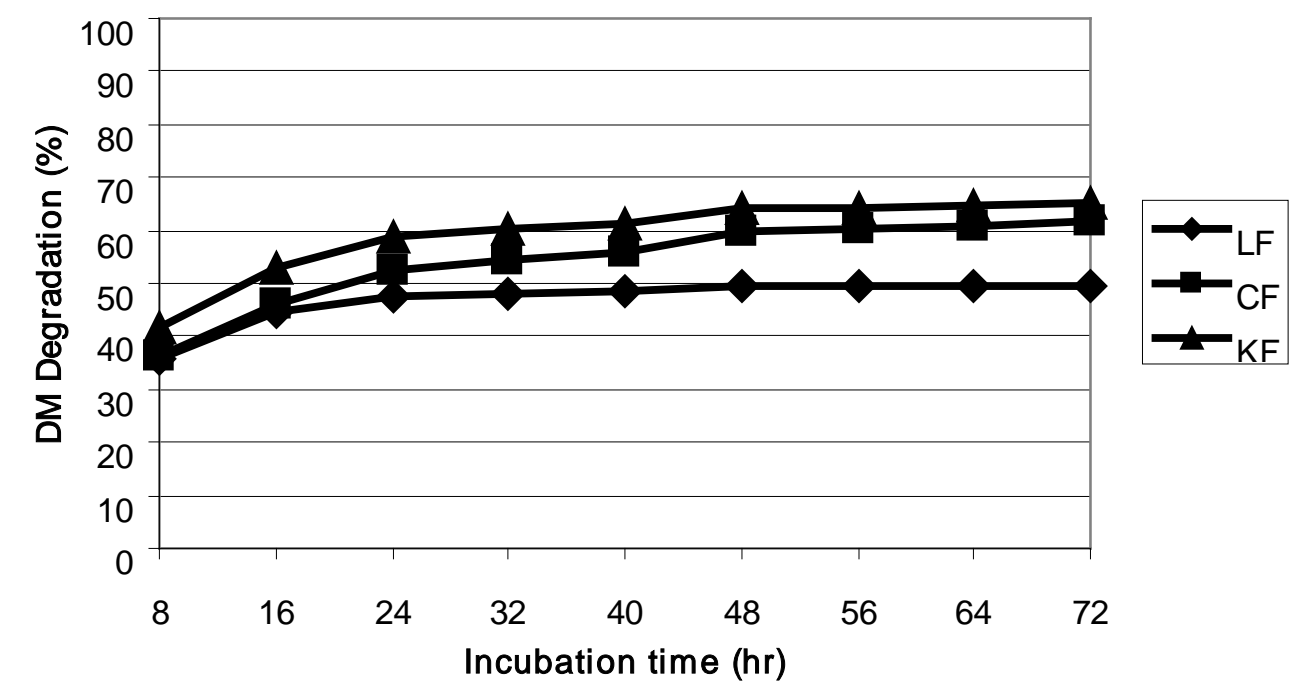

b) $\mathbf{C P}$

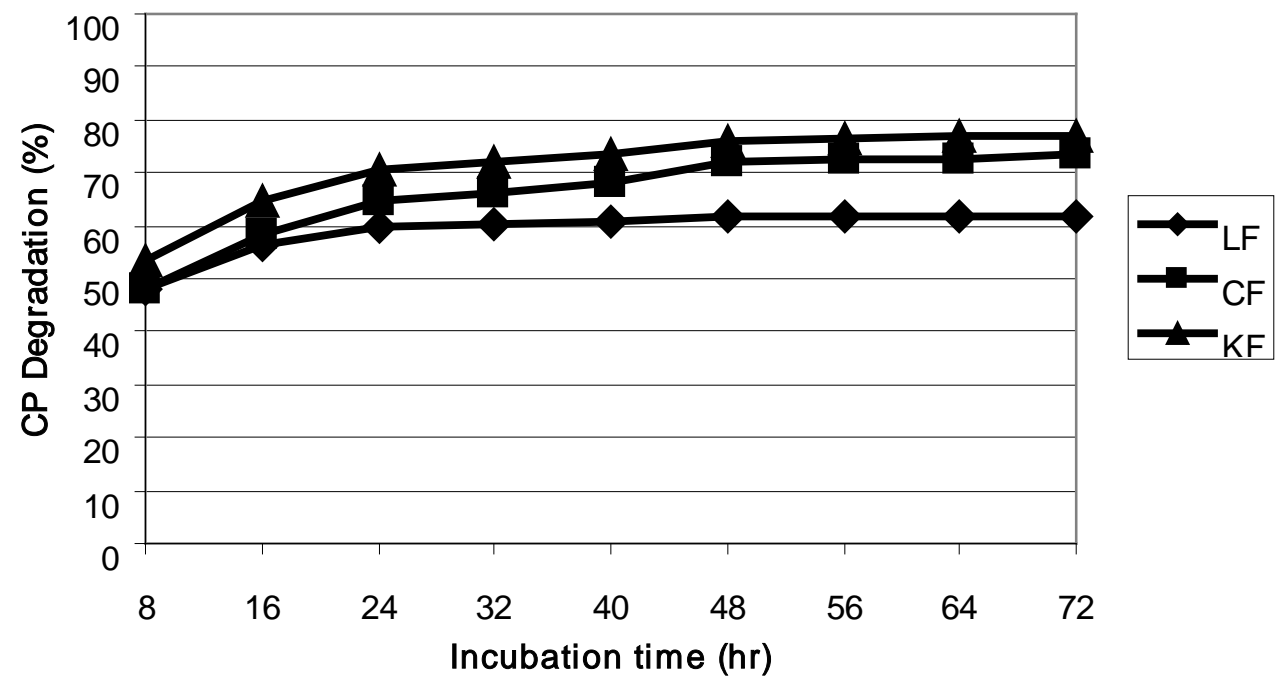

Figure 1 Ruminal degradation of the dry matter (DM) (a) and crude protein (CP) (b) of leucaena fodder $(\diamond \mathrm{LF})$, Madras thorn fodder $(\boldsymbol{} \mathrm{CF})$ and moringa fodder $(\boldsymbol{\Delta} \mathrm{KF})$ over an incubation period of 72 hours.

Table 3 shows intestinal digestibility of DM and CP that is undegraded in the nylon bag incubated $16 \mathrm{~h}$ in the rumen when measured using different methods. Dry matter and CP intestinal digestibilities of both Madras thorn and moringa fodder were significantly $(P<0.05)$ higher than for leucaena fodder. Intestinal digestibilities were within the range of $30.2 \%$ to $37.5 \%$, and $38.1 \%$ to $44.3 \%$ for DM and CP, 
respectively. The DM and CP intestinal digestibility measured with the MNB without pepsin- $\mathrm{HCl}$ was lower $(P<0.05)$ than those of MNB with pepsin- $\mathrm{HCl}$ and the three-step techniques. However, the DM and CP intestinal digestibilities measured with the MNB with pepsin- $\mathrm{HCl}$ were similar $(P>0.05)$ to the three-step method.

Table 2 Degradation parameters and effective degradation of dry matter (DM) and crude protein (CP) of tree fodder of Madras thorn, leucaena and moringa incubated in the rumen of cattle

\begin{tabular}{ccccc}
\hline Items & Leucaena & Madras thorn & Moringa & SEM \\
\hline DM degradability parameter (\%) & & & & \\
A & $13.7^{\mathrm{b}}$ & $19.7^{\mathrm{a}}$ & $19.8^{\mathrm{a}}$ & 1.42 \\
B & $36.0^{\mathrm{b}}$ & $42.4^{\mathrm{a}}$ & $45.4^{\mathrm{a}}$ & 2.33 \\
C & 0.11 & 0.06 & 0.06 & 0.01 \\
A + B & $49.7^{\mathrm{b}}$ & $62.1^{\mathrm{a}}$ & $65.2^{\mathrm{a}}$ & 3.62 \\
E (\%) & $39.1^{\mathrm{b}}$ & $43.1^{\mathrm{ab}}$ & $48.5^{\mathrm{a}}$ & 1.74 \\
CP degradability parameter (\%) & & & & \\
A & 14.5 & 15.7 & 12.9 & 1.25 \\
B & $31.1^{\mathrm{b}}$ & $38.5^{\mathrm{a}}$ & $39.9^{\mathrm{a}}$ & 1.58 \\
C & 0.10 & 0.09 & 0.12 & 0.01 \\
A + B & $45.6^{\mathrm{b}}$ & $54.2^{\mathrm{a}}$ & $52.8^{\mathrm{a}}$ & 1.61 \\
E (\%) & $35.0^{\mathrm{b}}$ & $40.4^{\mathrm{a}}$ & $41.4^{\mathrm{a}}$ & 1.46
\end{tabular}

$* \mathrm{E}$ : effective degradability at an outflow rate (fraction/h) of $0.05 / \mathrm{h}$.

$\mathrm{A}=$ the intercept of the degradation curve at time zero (\%); $\mathrm{B}=$ the fraction of $\mathrm{DM}$ and $\mathrm{CP}$ that will be degraded when given sufficient time for digestion in the rumen $(\%), c=$ a rate constant of disappearance of fraction $B(/ h)$.

a,b Means with different superscripts in the same row differ significantly $(P<0.05$.

SEM: standard error of the mean.

Table 3 Intestinal digestibility of rumen undegraded dry matter (DM) and crude protein (CP) of residues of tree fodder of Madras thorn, leucaena and moringa following $16 \mathrm{~h}$ incubation in the rumen

\begin{tabular}{ccccc}
\hline & Leucaena & Madras thorn & Moringa & SEM \\
\hline Intestinal DM digestibility (\%) & & & & \\
MNB without pepsin-HCl & $30.2^{\mathrm{c}}(\mathrm{B})$ & $35.1^{\mathrm{a}}(\mathrm{B})$ & $34.4^{\mathrm{b}}(\mathrm{B})$ & 0.53 \\
MNB with pepsin-HCl & $33.4^{\mathrm{b}}(\mathrm{A})$ & $37.3^{\mathrm{a}}(\mathrm{A})$ & $37.1^{\mathrm{a}}(\mathrm{A})$ & 0.45 \\
A three-step & $33.4^{\mathrm{b}}(\mathrm{A})$ & $37.5^{\mathrm{a}}(\mathrm{A})$ & $37.4^{\mathrm{a}}(\mathrm{A})$ & 0.49 \\
Intestinal CP digestibility (\%) & & & & \\
MNB without pepsin-HCl & $38.1^{\mathrm{b}}(\mathrm{B})$ & $43.4^{\mathrm{a}}(\mathrm{B})$ & $43.1^{\mathrm{a}}(\mathrm{B})$ & 0.64 \\
MNB with pepsin-HCl & $39.1^{\mathrm{b}}(\mathrm{A})$ & $44.2^{\mathrm{a}}(\mathrm{A})$ & $43.8^{\mathrm{a}}(\mathrm{A})$ & 0.57 \\
A three-step & $39.6^{\mathrm{b}}(\mathrm{A})$ & $44.3^{\mathrm{a}}(\mathrm{A})$ & $44.0^{\mathrm{a}}(\mathrm{A})$ & 0.53 \\
\hline
\end{tabular}

${ }^{a, b}$ Means with different superscripts in the same row differ significantly $(P<0.05)$.

(A, B) Means with different rows in the same column differ significantly $(P<0.05)$.

MNBL: mobile nylon bag.

Dry matter and CP degradation, intestinal and total tract digestibility of protein with different intestinal test methods are shown in Tables 4 and 5. In terms of ruminal DM and CP degradation, moringa fodder was higher $(P<0.01)$ than Madras thorn fodder, which was higher $(P<0.05)$ than leucaena fodder. Dry matter 
and CP of intestinal and total tract digestibility of Madras thorn fodder was higher $(P<0.01)$ than in moringa and leucaena fodders. In addition, DM and CP of intestinal and total tract digestibilities of moringa fodder was higher $(P<0.01)$ than in leucaena fodder. Dry matter and CP degradation, intestinal and total tract digestibility based on the MNB without pepsin-HCl were significantly lower $(P<0.05)$ than ones based on MNB with pepsin- $\mathrm{HCl}$ and the three-step techniques. However, the DM and $\mathrm{CP}$ intestinal digestibility measured with the MNB with pepsin- $\mathrm{HCl}$ were similar $(P>0.05)$ to the three-step method.

Table 4 Effect of tree fodder and methods on intestinal and total tract digestibility (\%) of dry matter

\begin{tabular}{lllll}
\hline & Leucaena & Madras thorn & Moringa & SEM \\
\hline $\begin{array}{l}\text { Rumen } \\
\text { Intestinal }\end{array}$ & $44.4^{\mathrm{b}}$ & $46.3^{\mathrm{ab}}$ & $52.9^{\mathrm{a}}$ & 2.58 \\
$\quad$ MNB without pepsin-HCl & $16.8^{\mathrm{b}}(\mathrm{B})$ & $18.8^{\mathrm{a}}(\mathrm{B})$ & & \\
$\quad$ MNB with pepsin-HCl & $18.6^{\mathrm{b}}(\mathrm{A})$ & $20.1^{\mathrm{a}}(\mathrm{A})$ & $16.2^{\mathrm{c}}(\mathrm{B})$ & 0.28 \\
$\quad 18.5^{\mathrm{c}}(\mathrm{A})$ & 0.26 \\
$\quad$ A three-step & & $20.1^{\mathrm{a}}(\mathrm{A})$ & $17.6^{\mathrm{c}}(\mathrm{A})$ & 0.26 \\
Total tract & $61.2^{\mathrm{c}}(\mathrm{B})$ & $65.1^{\mathrm{b}}(\mathrm{B})$ & $69.1^{\mathrm{a}}(\mathrm{B})$ & 0.78 \\
$\quad$ MNB without pepsin-HCl & $63.0^{\mathrm{c}}(\mathrm{A})$ & $66.4^{\mathrm{b}}(\mathrm{A})$ & $70.4^{\mathrm{a}}(\mathrm{A})$ & 0.74 \\
$\quad$ MNB with pepsin-HCl & $63.0^{\mathrm{c}}(\mathrm{A})$ & $66.4^{\mathrm{b}}(\mathrm{A})$ & $70.5^{\mathrm{a}}(\mathrm{A})$ & 0.75 \\
A three-step & & & \\
\hline
\end{tabular}

\footnotetext{
${ }^{\mathrm{a}, \mathrm{b}}$ Means with different superscripts in the same row differ significantly $(P<0.05)$.

(A, B) Means with different rows in the same column differ significantly $(P<0.05)$.

MNB: mobile nylon bag.
}

Table 5 Effect of tree fodder and methods on intestinal and total tract digestibility (\%) of crude protein

\begin{tabular}{llccc}
\hline & Leucaena & Madras thorn & Moringa & SEM \\
\hline Rumen & $39.2^{\mathrm{b}}$ & $45.0^{\mathrm{ab}}$ & $47.3^{\mathrm{a}}$ & 2.41 \\
$\quad$ Intestinal & & & \\
MNB without pepsin-HCl & $23.2^{\mathrm{ab}}(\mathrm{C})$ & $23.8^{\mathrm{a}}(\mathrm{A})$ & $22.7^{\mathrm{b}}(\mathrm{B})$ & 0.19 \\
MNB with pepsin-HCl & $23.8^{\mathrm{b}}(\mathrm{B})$ & $24.3^{\mathrm{a}}(\mathrm{A})$ & $23.1^{\mathrm{c}}(\mathrm{A})$ & 0.13 \\
A three-step & $24.1^{\mathrm{b}}(\mathrm{A})$ & $24.4^{\mathrm{a}}(\mathrm{A})$ & $23.2^{\mathrm{c}}(\mathrm{A})$ & 0.13 \\
Total tract & & & & 0.82 \\
MNB without pepsin-HCl & $62.4^{\mathrm{c}}(\mathrm{C})$ & $68.8^{\mathrm{b}}(\mathrm{A})$ & $70.0^{\mathrm{a}}(\mathrm{B})$ & 0.79 \\
MNB with pepsin-HCl & $63.0^{\mathrm{c}}(\mathrm{B})$ & $69.3^{\mathrm{b}}(\mathrm{A})$ & $70.4^{\mathrm{a}}(\mathrm{A})$ & 0.77 \\
A three-step & $63.3^{\mathrm{c}}(\mathrm{A})$ & $69.4^{\mathrm{b}}(\mathrm{A})$ & $70.5^{\mathrm{a}}(\mathrm{A})$ & \\
\hline
\end{tabular}

${ }^{\mathrm{a}, \mathrm{b}}$ Means with different superscripts in the same row differ significantly $(P<0.05)$.

(A, B) means with different rows in the same column differ significantly $(P<0.05)$.

MNB: mobile nylon bag.

\section{Discussion}

That leucaena fodder has lower DM and CP rumen and intestinal degradations relative to Madras thorn and moringa fodders may be owing to its high tannin, anti-nutritional content (Barry, 1987). In addition, Jones et al. (1994), Hove et al. (1996) and Tolera et al. (1998) reported that ruminal DM and CP disappearances of leucaena fodder were higher than $60 \%$, and nutrient digestibility in the intestine was also higher (Wheeler et al., 1994). Intestinal DM and CP degradation of Madras thorn fodder was the highest, 
followed by moringa and leucaena fodder. Total tract DM and CP degradation of moringa fodder was highest, followed by Madras thorn and leucaena fodder, because moringa fodder had the highest degradation in the rumen. Improvements in performance may be achieved by supplementing protein fodders to ruminants. Good candidates for supplementation are Madras thorn and moringa fodders, which contain high protein and high condensed tannin concentrations, which would increase by-pass protein from the rumen to the abomasum. This result was similar to those of Reed et al. (1982), Onwuka (1992) and Wanapat (2001).

The intestinal degradability of DM and CP with MNB without incubation in pepsin-HCl solution was lower $(P<0.05)$ than MNB with pepsin- $\mathrm{HCl}$ and the three-step in vitro methods. Differences among methods can be caused by variations in pepsin-HCl incubation and enzyme activities. With and without pepsin-HCl incubation, Voigt et al. (1985) and Van Straalen et al. (1993) observed intestinal digestibilities similar to those in the present experiment. Intestinal digestibilities of both $\mathrm{MNB}$ with pepsin- $\mathrm{HCl}$ and the three-step methods were higher $(P<0.05)$ than those of MNB without pepsin-HCl incubation method. The AOAC (1984) approved a standardized pepsin digestion procedure for estimating total tract unavailable CP. Pepsininsoluble $\mathrm{N}$ was strongly correlated with total tract unavailable $\mathrm{N}$ in forages (Goering et al., 1972; Shelford et al., 1980). A three-step procedure was developed by Calsamiglia \& Stern (1995) to estimated intestinal digestion of protein in ruminants. The technique was developed to closely simulate physiological conditions of ruminants, yet was rapid, reliable, inexpensive, and applicable to a wide variety of protein supplements.

It was concluded that the ruminal, intestinal and total tract digestibilities of DM and CP in Madras thorn and moringa fodder were significantly higher than those of leucaena fodder. The present results suggest that the in vivo and in vitro methods for estimating intestinal digestibility were not significantly different, but both methods necessitate the use of pepsin- $\mathrm{HCl}$ solution.

\section{Acknowledgements}

This work was supported by Suranaree University of Technology and the Higher Education Promotion and National Research University Project of Thailand (NRU), Office of the Higher Education Commission.

\section{References}

Antoniewicz, A.M., Van Vuuren, A.M., Van der Koelen, C.J. \& Kosmala, I., 1992. Intestinal digestibility of rumen undegraded protein of formaldehyde-treated feedstuffs measured by mobile bag and in vitro technique. Anim. Feed Sci. Technol. 39, 111-124.

AOAC, 1985. Official Method of Analysis. Association of Official Analysis Chemists. Washington, D.C., USA.

Aranachal, P.K., Karunanithi, K. \& Narendrababu, R., 2002. Comparative study on anthelmintic efficacy of neem products and Praziplus in sheep. Small Rumin. Res. 8, 131-132.

Barry, A., Jones, R.J. \& Murry, R.M., 1987. Secondary compounds of forages. In: Nutrition of Herbivores. Eds: Hecaker, J.B. \& Ternouth, J.H., Sydney, Australia. pp. 91-120.

Beckers, Y., Thewis, A. \& Maudoux, B., 1996. Intestinal digestibility of rumen undegradaded $\mathrm{N}$ of concentrates measured by the mobile nylon bag technique. Anim. Feed Sci. Technol. 61, 305-323.

Calsamiglia, S. \& Stern, M.D., 1995. A three-step in vitro procedure for estimating intestinal digestion of protein in ruminants. J. Anim. Sci. 73, 1459-1465.

Chen, X.B., 1996. An Excel Application Programme for Processing Feed Degradability Data. User Manual, Rowett Research Institute, Bucksburn, Aberdeen, UK.

Deacon, M.A., De Boer, G. \& Kennelly, J.J., 1988. Mobile nylon bag for estimating intestinal availability of rumen undegradable protein. J. Dairy Sci. 70, 977-982.

De Boer, G., Murphy, J.J. \& Kennelly, J.J., 1987. Mobile nylon bag for estimating intestinal available of rumen undegradable protein. J. Dairy Sci. 70, 977.

Goering, H.K. \& Van Soest, P.J., 1970. Forage Fiber Analysis (Apparatus, Reagents, Procedures and Some Application). Agric. Handbook No. 379. ARS, USDA, Washington, D.C., USA.

Goering, H.K., Gordon, C.H., Hemken, R.W., Waldo, D.R., Van Soest, P.J. \& Smith, L.W., 1972. Analytical estimates of nitrogen digestibility in heat damaged forages. J. Dairy Sci. 55, 1275-1280.

Hove, L., Chakoma, C. \& Dzowela, B.H., 1996. Comparative evaluation of L. diversifolia, L. pallida and L. leucocephala cv. Cunningham as supplements to veld hay. Leucnet. News, Nov. 3, 24-26. 
Jones, R.J., 1994. Management of anti-nutritive factors- with special reference to leucaena. In: Forage Tree Legumes in Tropical Agriculture. Eds: Gutteridge, R.C. \& Shelto, H.M., CAB International, Wallingford, U.K. pp. 216-231.

Kahindi, R.K., Abdulrazak, S.A. \& Muinga, R.W., 2007. Effect of supplementing Napier grass (Pennisetum purpureum) with Madras thorn (Pithecellobium dulce) on intake, digestibility and live weight gains of growing goats. Small Rumin. Res. 69, 83-87.

Onwuka, C.F.I., 1992. Tannin and saponin contents of some tropical browse species fed to goats. Trop. Agric. (Trinidad) 69, 176.

Ørskov, E.R. \& McDonald, I., 1979. The estimation of protein degradability in the rumen from incubation measurements weighted to rate of passage. J. Agric. Sci., Camb. 92, 499.

Paengkoum, P., 2010. Effects of neem (Azadirachta indica) and leucaena (Leucaena leucocephala) fodders on digestibility, rumen fermentation and nitrogen balance of goats fed corn silage. J. Anim. Vet. Adv. 9, 883-886.

Paengkoum, P. \& Paengkoum, S., 2010. Effects of supplementing rice straw with Leucaena (Leucaena leucocephala) and Madras thorn (Pithecellobium dulce) foliages on digestibility, microbial N supply and nitrogen balance of growing goats. Anim. Physiol. Anim. Nutr. 94, e59-e65.

Reed, J.D., McDowell, R.E., Van Soest, P.J. \& Horvath, P.J., 1982. Condensed tannins, a factor limiting the use of Madras thorn forage. J. Sci. Food Agric. 33, 2131.

Saha, H.M., Kahindi, R.K. \& Muinga, K., 2008. Evaluation of manure from goats fed panicum basal diet and supplemented with Madras thorn, leucaena or gliricidia. Tropical and Subtropical Agroecosystem 8, 251-257.

Sanchez, N.R., Sporndly, E. \& Ledin, I., 2006. Effect of feeding different levels of foliage of Moringa oleifera to creole dairy cows on intake, digestibility, milk production and composition. Livest. Sci. 101, 24-31.

SAS, 1998. User's Guide: Statistic, Versions 5. Edition SAS. Inst. Cary, N.C., USA.

Shelford, J.A., Cathcart, E.B., France, R.T. \& Debbs, J.L., 1980. A survey of composition and heat damage in dehydrated alfalfa products over the growing season from two B.C. processing plants. Can. J. Anim. Sci. 60, 197-200.

Steel, R.G.D. \& Torries, J.H., 1980. Principles and Procedures of Statistic a Biometereal Approach. (2 ${ }^{\text {nd }}$ ed), McGrow-FEIL New York: U.S.A.

Stern, M.D., Bach, A. \& Calsamiglia, S., 1997. Alternative techniques for measuring nutrient digestion in ruminants. J. Anim. Sci. 75, 2256-2276.

Tolera, A., Seyoum, M. \& Sundstøl, F., 1998. Nutritive evaluation of Leucaena leucocephala, L. diversifolia and L. pallida in Awassa, Southern Ethiopia. In: Forage Tree Legumes in Tropical Agriculture. Eds: Gutteridge, R.C. \& Shelto, H.M., CAB International, Wallingford, U.K. pp. 261-267.

Van Staalen, W.M., Booper, F.M.H., Antoniewiez, A.M., Kosmata, L. \& Van Vuuren, A.M., 1993. Intestinal digestibility in dairy cows of protein from grass and clover measured with mobile nylon bag and other methods. J. Dairy Sci. 76, 2970.

Van Vuuren, A.M., Bergsma, K., Krol-Kramer, F.F. \& Van Beers, J.A.C., 1989. Effects of addition of cell wall degrading enzymes on the chemical composition and the in sacco degradation of grass silage. Grass Forage Sci. 44, 223.

Voigt, J., Piatkowski, B., Engelmann, H. \& Rudolph, E., 1985. Measurement of the post-rumen digestibility of crude protein by the bag technique in cows. Arch. Tiereenaehr. 35, 555.

Waltz, D.M., Stern, M.D. \& Illg, D.J., 1989. Effect of ruminal protein degradation of blood meal and feather meal on the intestinal amino acid supply to lactating cows. J. Dairy Sci. 75, 1509-1518.

Wanapat, W., 2001. Role of Madras thorn hay as animal feed in the tropics. In: International Workshop Current Research and Development on Use of Madras thorn as Animal Feed. 23-24 July, 2001, Khon Kaen, Thailand. pp. 13-20.

Wheeler, R.A., Chaney, W.R., Cecava, M.J. \& Brewbaker, J.L., 1994. Forage yield and compositional analysis of leucaena species and hybrids adapted to cool sites. Agro. Syst. 25, 263-274. 